\title{
STUDENTS MISCONCEPTION IDENTIFICATION OF CHEMICAL CANDIDATES TEACHERS USING THREE TIER TEST METHOD IN THE BASIC CONCEPT OF CHEMICAL BOND
}

\author{
Napsin Palisoa' Dominggus Tahya, Victor Kayadoe \\ Chemistry Education Study Program, Faculty of Teacher \\ Training and Education - Pattimura University \\ *Email: nafsin_palisoa@yahoo.co.id
}

\begin{abstract}
Misconceptions possessed by prospective chemistry teacher students greatly affect the learning process when teaching in class, because the information or concepts conveyed to students are misconceptions. Prospective chemistry teacher students who experience misconceptions are simply reduced, because if a long misconception is left in the memory of the student there is a resistant misconception, namely a strong misconception that is difficult to reduce and constantly occurs. To find out whether the concepts stored in the memory of prospective chemistry teacher students, misconceptions need to be detected using the diagnostic three-tier test method. Diagnostic three-tier test method consists of 3 tiers, tier 1 is the choice of answers, tier 2 choices of reasons, and the third tier is the choice of the level of confidence of the answers and reasons. Diagnostic three-tier test method can detect misconceptions owned by students with the category of misconception 1 (M1), misconception 2 (M2), and misconception 3 (M3). The MK1 category students have the right answer choices, the wrong reason choices, but have the right beliefs, the M2 category students have the wrong answer choices, the right reason choices, but have the right beliefs, while the M3 category of students have the wrong answer choices, the wrong reason choices, but have confidence right. Detection test results using three-tier diagnostic methods, obtained from 32 students who took the test there are (28) $87 \%$ of chemistry teacher candidates experienced misconceptions (M1, M2, and M3). Prospective chemistry teacher students who have detected misconceptions on the basic concepts of chemical bonds need to be corrected, so that after graduating from college they do not bring misconceptions to students while teaching. Students' misconceptions can be reduced using an integrated $3 \mathrm{R}$ conceptual change (recall, recognition, and reintegration) (CC3R) strategy.
\end{abstract}

Keywords: Misconceptions, three tier test diagnostic method, chemical basic concepts, prospective chemistry teacher candidates.

\section{Introduction}

Prospective chemistry teacher students when experiencing misconceptions on the basic concepts of chemical bonds, resulting in students also experiencing misconceptions on further and complex chemical concepts. This statement is supported by Kean and Middlecamp (1985) explaining that chemistry has the characteristics of sequential and tiered concepts, so it is very important to understand basic chemistry correctly, because if the understanding of the basic concepts is wrong (misconception), than understanding of advanced concepts is also misconception. In addition, chemistry has the most important place among the other sciences, because chemistry can explain micro macro phenomena

Received September $18^{\text {th }} 2019$, Revision January 29th 2020 , Accepted for publication February $18^{\text {th }} 2020$.

Copyright (C) 2020 Published by FKIP - Unpatti, ISSN 2721-3110 
(Chittleborough \& Treagust, 2007; Chandarasegaran, Treagust, \& Mocerino, 2007). Several earlier studies give evidence that, misconceptions have occurred globally, both in schools and in universities. Understanding of misconceptions that occur in students (students and students) is influenced by two factors, namely external and internal factors (Suparno, 2005; Thompson \& Logue, 2006; Ibrahim, 2012). One external cause causing students' misconceptions is the teacher (Chiu, 2005; Taber, 2011). Misconceptions that occur in teachers cause misconceptions also occur in students (Barke et al, 2012; Al-Balushi et al, 2012; Chakraborty \& Mondal, 2012). Misconceptions often occur when students understand the basic concepts of chemistry in the classroom (Taber, 2009; Barke et al., 2010; Unal et al., 2010; Kolomuc and Tekin, 2011; Sheehan et al., 2012; Stojanovska et al., 2012). The results of earlier studies show that teachers experiencing misconceptions cause the potential for misconceptions in students. The results of the study are strengthened by the results of Abayneh's (2013) research, finding a significant correlation between the intensity of chemical misconceptions in students and teachers with a 90\% determination index value. Misconceptions also occur in prospective chemistry teacher students (Suyono, Masriyah, and Muchlis., 2015).

The results of the literature review show, in general, misconceptions occur in prospective chemistry teacher students, when becoming a teacher and teaching in class can cause students to accept concepts that are misconceptions, so that the transformation of misconceptions occurs continuously. To overcome the misconceptions that occur in teachers, the Educators and Teaching Staff especially chemistry education study programs as teacher producing institutions, have the responsibility in preparing prospective chemistry teachers who do not carry misconceptions when they graduate. Based on the problems expressed above, to find out whether the prospective chemistry teacher students of the FKIP Unpatti Chemical Education Study Program have the basic concepts of correct chemical bonds or misconceptions, it is necessary to give a misconception detection test using the three-tier test diagnostic method.

The problem at this time, namely how students can solve a problem correctly, if the information and concepts stored in long-term memory is a misconception concept, so the concept needs to be corrected first. This condition is supported by constructivist theory states that students (students) personally find and apply complex information, check new information compared to old information and correct old information if it is not right. If old conceptions or information are not right, it is necessary to change conceptions supported by cognitive theory requiring changes in concepts through assimilation and accommodation until equilibration occurs. Constructivist theory requires that it is necessary to correct old information if it is not in accordance with new concepts that are true through the accommodation process (Slavin, 2006; Suparno, 2001; Solso et al, 2008; Reed, 2011; Shunk, 2012). The accommodation process is carried out through four conditions, namely: (1) dissatisfaction, (2) intelligibility, (3) plausible, (4) fruitful (Posner, 1982).

\section{Method}

The design of this study went through 3 stages, namely (1) a preliminary study of theoretical and empirical studies, (2) the process of compiling misconception detection test questions using the diagnostic and validated three-tier test methods, and (3) misconception detection tests and analysis. The subjects in this study were 32 students of Chemistry Education Study Program candidates, using test instruments and data collection procedures in

Received September $18^{\text {th }} 2019$, Revision January $29^{\text {th }} 2020$, Accepted for publication February $18^{\text {th }} 2020$.

Copyright (C) 2020 Published by FKIP - Unpatti, ISSN 2721-3110 
the form of misconception detection tests, and analyzed using achievement percentages. Method three-tier diagnostic test has been developed to identify student misconceptions (Arslan et al., 2012). Criteria for grouping students belonging to the idea of the concept (KC), does not know the concept (DNKC), and misconceptions (M). The answers of student responses at each tier show in Table 1.

Table 1. Conception group criteria of student's conception based three-tier diagnostic test

\begin{tabular}{|c|c|c|c|c|}
\hline Tier1 & Tier2 & Tier3 & \multirow{2}{*}{ Group of Conception } & Abbreviation \\
\cline { 1 - 3 } Answer & Reason & Trust & & \\
\hline True & True & Sure & Know the concept & KC \\
\hline True & True & Not Sure & Does not know the concept & DNKC \\
\hline True & False & Not Sure & Does not know the concept & DNKC \\
\hline False & True & Not Sure & Does not know the concept & DNKC \\
\hline False & False & Not Sure & Does not know the concept & DNKC \\
\hline False & True & Sure & Misconception 1 & M1 \\
\hline True & False & Sure & Misconception 2 & M2 \\
\hline False & False & Sure & Misconception 3 & M3 \\
\hline
\end{tabular}

(Arslan et al., 2012)

Referring to the stated research objectives, this type of research can be classified into quantitative descriptive research. The research is classified into quantitative descriptive research because its main activity is analyzing the number of misconceptions possessed by chemistry teacher candidates in the FKIP Unpatti Chemistry Study Program. The research was conducted in August - October 2019 in the Chemistry Education Study Program, Department of Mathematics and Natural Sciences, FKIP Unpatti.

\section{Results}

\section{a. Concept Analysis and Preparation of Test Problems for Misconception Detection}

The results of the literature review and concept analysis, it is known that the basic concepts of chemistry including the concept of chemical bonds are still understood in a misconception both at home and abroad. The results of the literature study are also supported by a concept study conducted by the Researcher Team on the basic concepts of chemistry that have been studied by prospective chemistry teacher students in earlier lectures, namely in the Basic Chemistry Course, showing that there are still many conceptual understanding of the chemistry students wrong, including understanding the concept of the basic concepts of chemical bonds. Wherein it is known that the concept of chemical bonds is a basic concept for knowing advanced concepts, so that if a prospective chemistry teacher student experiences a misconception in the basic concept of chemical bonds, then the chemistry teacher candidate student has difficulty and misconceptions in understanding advanced concepts. Misconceptions possessed by prospective chemistry teacher students can be identified or detected using the three-tier test method. Three-tier test method, the method used to detect misconceptions by describing the suitability of the choice of answers with reason, and the level of student confidence in the answers given.

Received September $18^{\text {th }} 2019$, Revision January $29^{\text {th }} 2020$, Accepted for publication February $18^{\text {th }} 2020$. 


\section{b. Results of Misconception Detection Test}

A misconception detection test is carried out to determine the extent to which the concepts that have been stored in the cognitive structure (schemata) of students, whether the concepts stored are correct or are still misconceptions. The test results showed from 32 students there were $28(87 \%)$ experienced misconceptions on the test questions of the basic concepts of clam bond using the three-tier diagnostic test method. The results of misconception diagnostic tests showed that prospective chemistry teacher students experienced misconceptions in the category of misconception 1 (M1), misconception 2 (M2), and misconception 3 (M3). Where M1 shows correct answer choices, reasons are wrong, but sure, M2 students have wrong answers, reasons are right, but sure, and M3 students have wrong answers, reasons are wrong, but sure. The results of misconception detection tests can be seen in Figure 1.

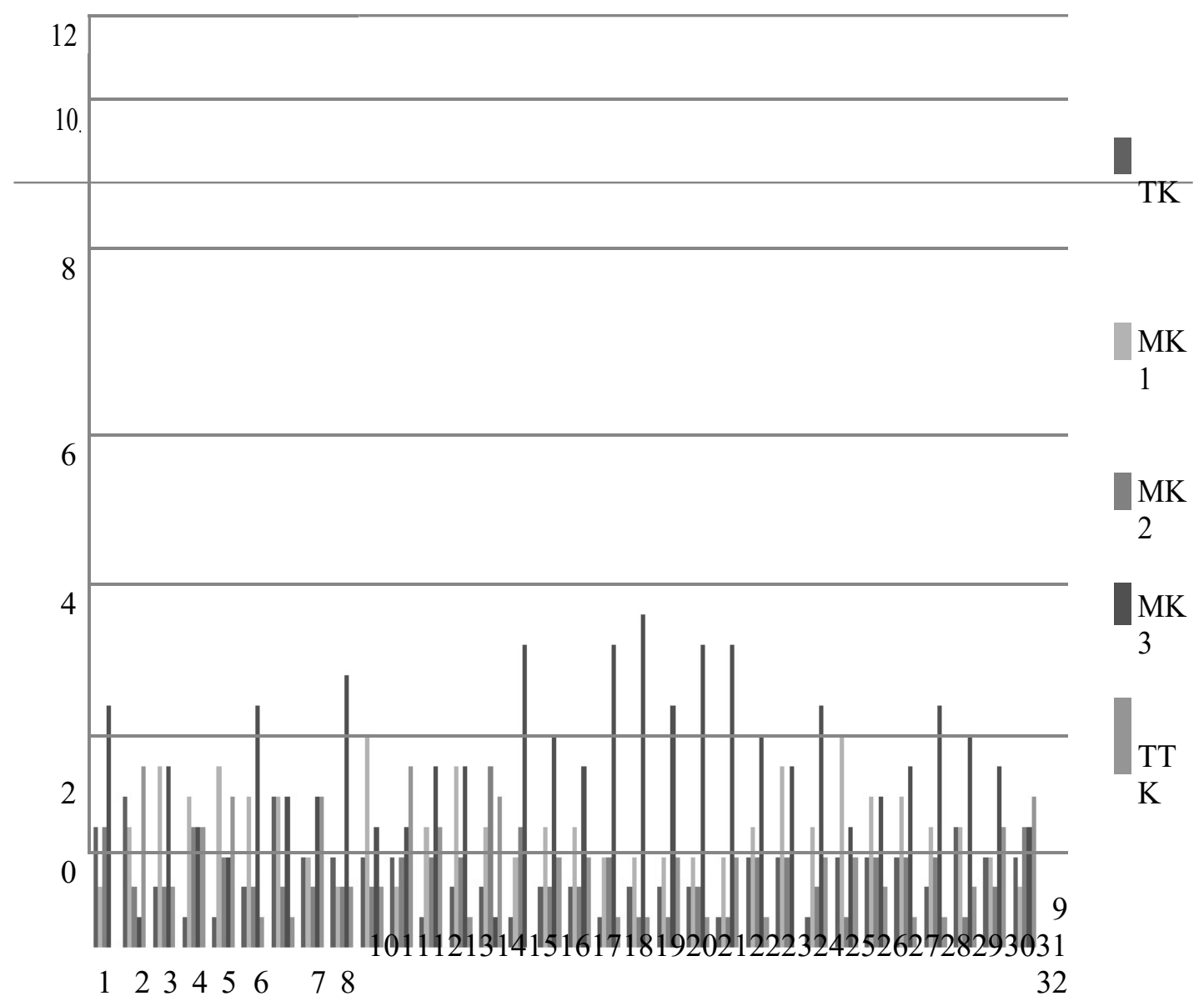

Figure 1. Misconceptions Detection Test Diagram

Figure 1, shows an overview of the concept of chemistry teacher candidates during the misconception detection test using the three tier diagnostic test method. A total of 18 chemical bond test questions were given, out of 32 chemistry teacher candidates who took the test, the percentage of misconceptions was higher than the presentation of students who knew 
the concept. This shows that the understanding of the concept of chemical bonds is still a misconception, so it needs to be fixed as soon as possible.

\section{Discussion}

The analysis results of the misconception detection test showed that of 32 students who took the test, there were $27(87 \%)$ students who experienced misconceptions. The results of this study also occurred in the research of Suyono et al. (2015) states that misconceptions also occur in prospective chemistry teacher students. This result is very worrying, so that students' misconceptions need to be repaired as quickly as possible, because if left unchecked after graduating from college and becoming a teacher later, teachers experiencing misconceptions can easily transfer misconceptions to students. This statement is reinforced by the results of Abayneh's research (2013), finding a significant correlation between the intensity of chemical misconceptions in students and teachers with a $90 \%$ determination index value. In addition, teachers, especially chemistry teachers who experience misconceptions on the basic concepts of chemistry, cannot improve students 'misconceptions that are misconceptions, so that misconceptions increase and are stronger stored in students' memories. This statement is reinforced by the results of Unal et al. (2010) showed that students' misconceptions of the concept of covalent bonding increased after learning in class.

This condition also causes both teachers and students to experience difficulties and obstacles in understanding advanced and more complex concepts. According to Berg (2012) if misconceptions among students (students) are difficult to correct, resulting in students having difficulty in working on more difficult questions. Gardner (2004) believes preconception is often a misconception for students. This opinion is reinforced by Barke et al. (2009) that the effect of achieving student learning outcomes is due to the misconception of students who are misconceptions, because it can affect students' understanding when constructing the conception itself. The same thing also happens to the basic concepts of chemistry, especially the basic concepts of chemical bonds, if prospective chemistry teacher students experience misconceptions on the basic concepts of chemical bonds, then students have difficulty in understanding advanced concepts, because chemical bonds are the basic concepts for understanding the concept another. This statement is supported by Middlecamp and Kean (1985) explaining that chemistry has the characteristics of sequential and tiered concepts, so it is very important to understand basic chemistry correctly, because if the understanding of the basic concepts is wrong (misconception), then understanding of advanced concepts also misconception.

\section{Conclusion}

Based on the results of research that has been done it can be concluded that:

1. The Three Tier Test Diagnostic method can detect the misconceptions of prospective chemistry teacher students on the basic concepts of chemical bonds FKIP Unpatti Chemical Education Study Program.

2. The results of the misconception detection test showed that of 32 chemistry teacher candidates who took the misconception detection test, there were 27 (87\%) students still experiencing misconceptions in the category of misconception 1 (MC1), misconception 2 (MC2), and misconception (MC3).

Received September $18^{\text {th }} 2019$, Revision January $29^{\text {th }} 2020$, Accepted for publication February $18^{\text {th }} 2020$.

Copyright (C) 2020 Published by FKIP - Unpatti, ISSN 2721-3110 


\section{References}

Al-Balushi, S. M., Ambusaidi, A. K., Al-Shuaili, A.H., Taylor, N. (2012). Omani twelfth grade students' most common misconceptions in chemistry. Internasional Council of Associations for Science Education. Vol.23, No.3, September 2012. Pp. 221-240.

Barke, H.D., Al Hazari, and Yitbarek, S. (2009). Misconceptions in Chemistry. Berlin: Springer Link.

Creswell, J. W. (2014). Research Design. Qualitative, Quantitative, and Mixed Methods Approacher. 3th Edition. Sage Publications. Thousand Oaks California.

Chakraborty, A. \&Mondal, B.C. (2012). Misconceptions in Chemistry at IX th Grade And Their Remedial Measures. Indian Streams Research Journal. Vol 2, Issue. 7, Aug 2012. pp. 1-9.

Dale H. Schunk. (2012). Learning Theories. An Educational Perspective. Published under licence Pearson Education, Inc.

Duncan, R.M. (1995). Piaget and Vygotsky revisited: Dialogue or assimilation. Developmental Review. 15. 458-472.

Gajewski, A. \& Mather, M. (2015). Remediation Strategies for Learners At Risk of Fallure: A Course Based Retention Model. General Education and Liberar Studies at Centennial College.

Ghazanfari M., Ziaee M., Sharifianfar E. (2014). The Impact of Illustration on Recall of Short Stories. Internaational Conference Current Trends in ELT.

Kolomuc, A. \& Tekin, S. (2011). Chemistry Teachers' Misconceptions Concerning Concept ofChemical Reaction Rate. Eurasian: Journal Physics and Chemistry Education. Vol.3 No.2, pp.84-101.

Middlecamp, C. \& Elizabeth Kean. (1985). Panduan Belajar Kimia Dasar. Jakarta: PT.

Gramedia.

Ochiai, S., Kato, M. P. \& Tanak, K. (2014). Re-call and Re-cognition in Episode Reretrieval: A User Study on News Re-finding a Fortnight Later. Journal Kyoto Universisy, Yoshida

Honmachi, Sakyo, Kyoto, Japan.

Orgill, M. \& Sutherland, A. (2008). Undergraduate Chemistry Students' Perception of and Misconception about Buffer Problems. Chemistry Education Research. 9:131-143.

Pesman, H. \& Eryilmaz, A. (2010). Development of a Three-Tier Test to Assess Misconceptions about Simple Electric Circuits. The Journal of Educational Research. Vol. 103, pp.208-222.

Posner, G. J., Strike, K. A., Hewson, P. W. (1982). Accommodation of a Scientific Conception: Toward a Theory of Conceptual Change Departement of Education, Cornell University, Ithaca. New York.

Schunk, D. H. (2012). Learning Theories: An Educational Perspective; $6^{\text {th }}$ Edition. Boston: Pearson Education, Inc.

Sheehan M., Peter E.C., Hayes S. (2014).The Chemical Misconceptions of Pre-service Science Teachers at the University of Limerick: Do they change. Departement of Chemical and Enviromental Science \& National Centre for Excellence in Mathematics and Science Teaching and Learning. University of Limerick. Ireland.

Received September $18^{\text {th }} 2019$, Revision January $29^{\text {th }} 2020$, Accepted for publication February $18^{\text {th }} 2020$.

Copyright (C) 2020 Published by FKIP - Unpatti, ISSN 2721-3110 
Slavin, E.R. (2006). Educational Psychology. Theory and Practice. USA: Pearson.

Stojanovska M. I., Bojan T. Š., \& Vladimir, M. P. (2012). Addressing Misconceptions about the Particulate Nature of Matter among Secondary-School and High-School Students in the Republic of Macedonia. Institute of Chemistry, Faculty of Natural Sciences and Mathematics, Ss. Cyril \& Methodius University, Skopje, Macedonia Academy of Sciences and Arts.

Solso, R. L., Maclin, O. H., Maclin, M. K. (2005). Cognitive Psychology. $8^{\text {th }}$ Edition. Pearson Education, Inc.

Suyono, Masriyah, dan Muchlis. (2015). Preparasi Sarjana Pendidikan Kimia Tanpa Miskonsepsi Di FMIPA Unesa. Laporan Akhir Penelitian Unggulan Perguruan Tinggi. Bidang Unggulan. Tanpa Publikasi.

Unal S., Costu B., Ayas A. (2010). Secondary School Students' Misconception of Covalent Bonding. Journal of Turkish Science Education. 